\title{
Preelection Judicial Review: Taking the Initiative in Voter Protection
}

The citizens of California frequently use their power of initiative, ${ }^{\prime}$ often to make sweeping changes $\mathrm{im}$ the powers and duties of government and the people. ${ }^{2}$ There are various requirements an initiative measure must meet in order to be vahid. These include form and title and summary requirements, as well as requirements that the initiative consist only of one subject and not amount to a revision of the constitution. These requirements exist primarily to prevent voter confusion and deception.

In a series of recent cases, culminatimg with Brosnahan v. Brown, ${ }^{3}$ the California Supreme Court reviewed initiative proponents' compliance with these statutory and constitutional requirements. In each case, the challenges were heard after the initiative measures were approved by a majority of the voters, and in each case, the court held the ineasure valid.

Judicial review of an initiative's validity may be invoked before the measure is submitted to the voters. ${ }^{4}$ The question before the court in either preelection or postelection hitigation is the same: Have the proponents of the initiative measure, or the state officials required to act on the measure, comphed with their statutory and/or constitutional

1. The power of initiative, currently CAL. CoNST. art. II, $\$ 8$, was adopted in 1911. Since that time, over 170 initiative proposals have been submitted to the voters. See REFERENDUMs 91 (D. Butler \& A. Ranney eds. 1978) (155 proposals from 1912 to 1976); CALIForNIA SECRETARY OF State, Statement of Vote (General Election Nov. 2, 1982) (five initiative proposals); id. (Primary Election June 8, 1982) (four); id. (General Election Nov. 4, 1980) (one); id. (Primary Election June 3, 1980) (three); id. (Special Election Nov. 6, 1979) (one); id. (General Election Nov. 7, 1978) (three); id. (Primary Election June 6, 1978) (one). "The institution appears as firmly grounded in the pohtical culture of the state as the legislature itself. Indeed, the initiative may be more widely employed and by more people in the state than in any other democratic society in the world." REFERENDUMS, supra, at 88.

2. See, for example, the Political Reform Act of 1974, proposed and adopted by initiative in 1974, CAL. Gov'T CODE $\$ 81000-91014$ (West 1976 \& Supp. 1983), and the comprehensive taxation and spending limitations adopted im 1978, CAL. Const. art. XIIIA (Proposition 13), and in 1979, CAL. Const. art. XIIIB (Proposition 4).

3. 32 Cal. 3d 236, 651 P.2d 274, 186 Cal. Rptr. 30 (1982).

4. This is usually done under CAL. CIv. Proc. CODE $\$ 1085$ (West 1980) (writ of mandate). See, e.g., Brosnahan v. Eu, 31 Cal. 3d 1, 3, 641 P.2d 200, 201, 181 Cal. Rptr. 100, 101 (1982). Other states have specific provisions for preelection review of initiative measures. See, e.g., Colo. Rev. Stat. \$\$ 1-40-101(3), -102(3) (1980); OKLa. Stat. ANN tit. 34, \$\$ 8-10 (West 1976). In addition, review in states including Califorma is available under general provisions of administrative law. See CAL. CIV. Proc. CODE $\$ \S 1067-1105$ (West 1980 \& Supp. 1983) (writs of review, mandate, and prohibition); ME. REv. STAT. ANN. tit. 5, $\$$ 11001-11008 (1979 \& Supp. 1982); MASS. GEN. LAWS ANN. eh. 30A, $\& 14$ (West 1979) (judicial review of administrative action). 
duties? Realistically, lowever, the answer is determined by the timing of the litigation, for courts invalidate initiative measures only in preelection litigation; ${ }^{5}$ once the measure has been approved in an election, it acquires an almost irrebuttable presumption of validity. Preelection review is thus preferable for two reasons. First, it promotes the voter protection intended by the restrictions on the initiative process. Second, it gives the proponents of an initiative ineasure time to cure any defects before the election, thus saving time and money while allowing valid measures to be placed before the voters.

This Comment argues that preelection review of the form, singlesubject, and nonrevision requirements is necessary for adequate protection of the voters. Part I reviews the regulations and requirements of the initiative process. Part II discusses current judicial rules governing when to review compliance witlı those requirements. Part III suggests that postelection review is an inherently inadequate method of review, even if the court is willing at that time to give effect to these requirements. Fimally, Part IV suggests alternative methods of obtaining complete, but not overreaching, preelection judicial review.

I

\section{Regulation of the Initiative Process}

Seventeen states allow their citizens to propose botli statutes and amendments to the constitution; ${ }^{6}$ six states and the District of Columbia allow initiatives for statutes only. ${ }^{7}$ The initiative can be eitler mdirect, ineaning subinitted to the legislature, or direct, subinitted only to the voters. ${ }^{8}$

5. In modern litigation, no initiative measure has been invalidated after the election for noncounpliance with the requirements of the initiative process. This does not mean that initiative measures are never imvalidated in postelection litigation, only that this mvalidation is based on entirely different grounds, usually violation of the United States Constitution or analogous provisions in state constitutions. See cases cited in Comment, The Direct Initiative Process: Have Unconstitutional Methods of Presenting the Issues Prejudiced its Future?, 27 U.C.L.A. L. REv. 433, 439 n.35 (1979).

6. These states, their enabling constitutional provisions, and dates of original adoption are: ARIz. ConST. art. IV, pt. 1, \& 1 (1910); ARK. Const. amend. 7 (1920); CAL. ConST. art. II, §§ 8, 10 (1911); Colo. Const. art. V, \& 1 (1910); Fla. ConsT. art. XI, \& 3 (1968); Ill. ConsT. art. XIV, § 3 (1970); MASS. CoNST. amend. art. 48 (1918); Mich. CoNST. art. II, $\$ 9$ (1908) (laws); id. art. XII, $\S 2$ (1908) (constitutional amendments); Mo. CoNST. art. III, $\S 49$ (1908); MONT. CoNST. art. III, $\S 4$ (1972) (laws); id. art. XIV, § 9 (1972) (constitutional amendments); NeB. ConsT. art. III, $\$ 2$ (1912); Nev. Const. art. XIX, $\S 1$ (1912); N.D. ConsT. art. III, $\S 1$ (1914); Ohio Const. art. II, $\S \S 1 \mathrm{a}-1 \mathrm{~g}$ (1912); OKLA. Const. art. V, § 2 (1907); OR. CoNST. art. IV, § 1 (1902); S.D. CoNST. art. III, $\& 1$ (1898) (laws); id. art. XXIII, $\$ 1$ (1972) (constitutional amendments).

7. These states, their euabling constitutional or statutory provisions, and effective dates of adoption are: ALASKA CONST. art. XI, § 1 (1959); D.C. CODE ANN. § 1-282 (1981) (approved by Congress and effective in 1978, H.R. Con. Res. 464, 95th Cong., 2d Sess., 124 CoNG. REC. 4706 (1978)); IdAho CoNST. art. III, $\$ 1$ (1912); ME. ConsT. art. IV, pt. $3, \S 18$ (1909); UTAH CoNST. art. VI, $\S 1$ (1900); WASH. CoNST. art. II, § 1 (1912); WYO. CoNST. art. III, § 52 (1968).

8. See Comment, The Scope of the Initiative and Referendum in California, 54 CALIF. L. 
Although regulation of the initiative process varies from state to state $^{9}$ the general pattern is the same. After drafting an initiative ineasure, the proponents submit it to a state official who reviews its form and prepares the petitions to be circulated. ${ }^{10}$ The proponents then circulate the petitions and obtain the requisite number of voters' signatures. ${ }^{11}$ A state official subsequently verifies the signatures collected. ${ }^{12}$ At some point in this process, a state official prepares a title and summary, which in most states appear on both the petitions and the ballot. ${ }^{13}$ This Part reviews the standards established by statute and the courts in each of these areas.

\section{A. Contents of the Initiatve Petition}

\section{Form and Signature Requirements}

Most states have detailed rules governing the form of the mitiative petition. It must be of a certain size and mclude various items: for example, the full text of the measure proposed, language indicating it is a measure subinitted to the voters, a warning of criminal sanctions for false circulation or signatures, and a space for the circulator to attest to

REV. 1717, 1719-20 (1966). In Massachusetts, the initiative for constitutional amendments is strictly indirect; the proposals are referred to the voters only after action, if any, by the legislature. MAss. Const. amend. art. 48, Init., pt. 4, $\S \S 2-5$. In Maine, Massachusetts and Wyoming, the initiated statute will be referred to the voters only if the legislature does not enact it. ME. CoNST. art. IV, pt. 3, § 18; MASS. Const. amend. art. 48, Init., pt. 5, § 1; WYo. Const. art. III, § 52(d). In Utah and Washington, voters may propose either direct or indirect initiatives. UTAH CODE ANN. $\S \S 20-11-2,-3$ (Supp. 1979); W ASH. CoNST. art. II, § 1. In all other states Iisted at supra notes 6-7, the initiated measures are submitted directly to the voters.

9. Each state's provisions differ in some respect from the general rules listed here. Only Florida, Illinois, and Massachusetts depart from this general pattern. Florida permits initiative amendments only to its constitution. FLA. ConST. art. XI, \&3. lllinois permits mitiative amendments only to artiele IV of its constitution, which specifies the powers and duties of the legislature. ILL. CONST. art. XIV, §3. Massachusetts permits only indirect initiatives for constitutional amendments, which inust be approved by the legislature in order to be referred to the voters. MAss. CoNST. amend. art. 48, Init., pt. 4, $\$ \S 2-5$. Many states have different rules for initiativcs at county, district, or municipal levels. See Comment, supra note 8, at 1720; Note, The Proposed National Initiative Amendment: A Participatory Perspective on Substantive Restrictions and Procedural Requirements, 18 HARV. J. ON LEG1S. 429, 430 nn.6-7 (1981).

10. Usually this submission is to the Secretary of State. Buf see, e.g., CAL. Elac. Code $\S 3502$ (West 1977) (subinission to Attorney General).

11. See, e.g., CAL. Const. art. II, § 8(b); CAl.. Elec. Code $§ 3524$ (West Supp. 1983) (eight percent of votes cast in the prior gubernatorial election to qualify initiative constitutional amendment, five percent to qualify initiative statute).

12. Again, this official is usually the Secretary of State. See, e.g., Cal. Elec. Code $\S 3520$ (b) (West Supp. 1983). But see, e.g., Alaska Stat. $\$ 15.45 .150$ (1976) (Lieutenant Governor); OKLA. Stat. ANN. tit. 34, $\$ 8$ (West 1976) (Supreme Court).

13. The title and summary are usually prepared by the Attorney General. See, e.g., CAL. Elec. Code $\$ 3502$ (West 1977). But see, e.g., ALASKa STAt. \$15.45.180 (1982) (Lieutenant Governor, with the assistance of the Attorney General); ARIz. REv. STAT. ANN. § 19-125D (Supp. 1982) (Secretary of State). 
the validity of the signatures collected. ${ }^{14}$

The signatures, addresses, and other information obtained froin each signer also must be in a certain form. ${ }^{15}$ When petitions are submitted for verification by state officials, these items are checked against the voter registration records. ${ }^{16}$ Some states allow the initiative proponents to gather additional signatures if the number originally submitted is imsufficient. ${ }^{17}$

Although Califorma statutes specify exact forms to be used by initiative proponents ${ }^{18}$ and exact procedures to be used by the Secretary of State in reviewing signatures, ${ }^{19}$ in practice the courts invoke the doctrime of substantial comphance to overlook inany technical but harmless violations. ${ }^{20}$ Other states have similar substantial compliance rules; ${ }^{21}$ in general they seek to avoid encuubermg the initiative with overly technical requirements. ${ }^{22}$ This doctrine has its limits, however. In a recent California case, the proponents directed petition signers to list the addresses that appeared on their voter registration forms. The

14. See, e.g., CAL. ELEC. CODE $\$ 3501$ (West 1977). Most states also require the circulator to certify by affidavit that the signatures are genuine. See, e.g., id. $\$ 3519$ (West 1977).

15. See, e.g., CAL. Elec. Code $\S 3516$ (West 1977); Mo. ANN. STAT. $\S 116.040$ (Vernon Supp. 1982); NEB. Rev. STAT. § 32-703 (1978).

16. CAL. Elec. Code $\S 3521$ (b) (West Supp. 1983). Six states allow all or part of this verification to be done by random sampling. See, e.g., id. $\S 3520$ (d).

17. OHio Rev. Code ANN. \$3519.16 (Page 1972); UTAH Code ANN. \$ 20-11-16 (Supp. 1979). This was previously allowed in California. Act of July 19, 1966, ch. 161, § 6, 1966 Cal. Stats. 1st Spec. Sess. 710, 712, repealed by Act of Oct. 9, 1974, ch. 1543, § 3, 1974 Cal. Stats. 3531, 3532.

18. Cal. Elec. Code $\S \S 3501,3516,3519$ (West 1977).

19. Id. $\S \S 3520-3521$ (West Supp. 1983).

20. Assembly of California v. Deukmejian, 30 Cal. 3d 638, 652-53, 639 P.2d 939, 948, 180 Cal. Rptr. 297, 306 (referendum petitions), appeal dismissed and cert. denied, 456 U.S. 941 (1982); California Teachers Ass'n v. Collins, 1 Cal. 2d 202, 204, 34 P.2d 134, 134 (1934). This is part of the courr's tradition of liberal construction of provisions governing the initiative process. Comment, supra note 5, at 439-40; Comment, supra note 8, at 1743.

See also Brosnahan v. Eu, 31 Cal. 3d 1, 641 P.2d 200, 181 Cal. Rptr. 100 (1982), where the Secretary of State initially refused to certify Proposition 8 for the June 1982 ballot. The random sample of initiative petitions produced valid signatures constituting $108.76 \%$ of the required number; the statute required $110 \%$ for immediate certification. CAL. ELEC. CODE $§ 3521$ (a) (West Supp. 1983). The Secretary began the process of individual certification of each signature. Subsequently, the Secretary invoked the "substantial compliance" rule, and certified the initiative measure for the ballot despite lack of compliance with the statute. Opponents of the initiative challenged the Secretary's decision, and the legislature then made a one-time change of the qualifying number, based on a random sample, from $110 \%$ to $105 \%$. Act of Mar. 8, 1982, cl. 102, § 1, 1982 Cal. Legis. Serv. 481, 482 (West). The court apparently deferred to the legislature, noting simply that "the initiative measure should be placed on the ballot." Brosnahan v. Eu, 31 Cal. 3d at 3-4, 641 P.2d at 201, 181 Cal. Rptr. at 101.

21. See, e.g., State ex rel. Morris v. Marsh, 183 Neb. 521, 529-32, 162 N.W.2d 262, 268-69 (1968); Oklahomans for Modern Alcoholic Beverage Controls, Inc. v. Shelton, 501 P.2d 1089, 1092-94 (Okla. 1972). (1976).

22. See, e.g., Newsone v. Board of State Canvassers, 69 Mich. App. 725, 245 N.W.2d 374 
court held this not to be substantial compliance with the requirement that signers must list their current addresses. ${ }^{23}$ Deliberately circumventing the verification procedures defeated the very purpose of the regulation. ${ }^{24}$

\section{Title and Summary Requirements}

The proponents submit their measure to the Attorney General ${ }^{25}$ for a brief summary of its provisions and a title. ${ }^{26}$ The title and summary are intended to describe fairly the provisions of the measure. ${ }^{27}$ Further, the ballot title and statements must be structured so that a "yes" or "no" vote does not have an unintended opposite effect. ${ }^{28}$ Other statements may be required from state officials regarding the provisions of the initiative measure and their likely effects. ${ }^{29}$ In addition, the voters' pamphlet distributed by the state usually contains prepared arguments for and against each measure. ${ }^{30}$

California courts have long applied the substantial compliance doctrine to the Attorney General's work. If the statement is true and impartial, and would not mislead petition signers or voters, it will be upheld even if it incompletely catalogues the mitiative's provisions. ${ }^{31}$

\section{B. Contents of the Initiative Measure: Scope and Subject Matter Requirements}

Scope and subject matter restrictions go beyond the protection and

23. Assembly of California v. Deukmejian, 30 Cal. 3d at 648, 639 P.2d at 945, 180 Cal. Rptr. at 303 .

24. The purpose of this requirement, according to the court, was to allow officials to determine whether the signer was registered to vote where he or she resides. If not, the person was not qualified to sign an initiative petition. Id. at 647-49, 639 P.2d at 944-45, 180 Cal. Rptr. at 302-03. The court had warned in an eartier case that " 'substantial compliance' may be carried too far [and] nnay not be relied upon to save carelessly or negligently prepared petitions." California Teachers Ass'n v. Collins, 1 Cal. 2d 202, 205, 34 P.2d 134, 135 (1934).

25. In some states, other officials perform this function. See supra note 13.

26. Ordinarily, the Attorney General is not permitted to question the validity of the measure at this stage. Schmitz v. Younger, 21 Cal. 3d 90, 93, 577 P.2d 652, 653, 145 Cal. Rptr. 517, 518 (1978). Judicial review of the title or summary, however, is usually immediately available. See, e.g., Epperson v. Jordan, 12 Cal. 2d 61, 82 P.2d 445 (1938); WASH. REv. CODE ANN. $\$ 29.79 .060$ (Snpp. 1983). Some states permit advisory suggestions to be made to the proponents. E.g., IDAHO CODE § 34-1809 (1981) (Attorney General); WASH. REv. CODE ANN. § 29.79.015 (Supp. 1983) (reviser of state codes).

27. See, e.g., CAL. Elec. Code § 3502 (West 1977) (summary); id. § 3530 (ballot title).

28. The ballot titles must not be "designed in such a manner that a vote 'for' the issue would be a vote against . . . " ARK. STAT. ANn. § 2-208 (Supp. 1981). Accord OKLA. STAT. ANN. tit. 34, §9(A) (West 1976).

29. See, e.g., CAL. Elec. CODE $\S 3504$ (West 1977) (statement and estimate of effect, if any, on state or local revenues or expenditures).

30. See Comment, supra note 5, at 440-41.

31. See, e.g., People v. Frierson, 25 Cal. 3d 142, 187, 599 P.2d 587, 614, 158 Cal. Rptr. 281, 308 (1979). 
disclosurc purposes of the form and circulation requirements. While still protecting the public, these content restrictions place distmct limits on the people's initiative power, and may disallow even the most clearly understood and earnestly desired initiative.

\section{The Single-Subject Requirement}

Virtually all states require initiative measures to contain only one subject. ${ }^{32}$ There are two purposes behind this requirement. The first is prevention of voter confusion. ${ }^{33}$ Limiting an initiative to a smgle subject assures that the measure can be readily understood and referred to through use of a short summary. ${ }^{34}$ The second purpose is prevention of logrolling, which is the combination of several propositions within a single initiative. A logrolling ineasure could receive majority approval when some of the component measures would not liave been approved if submitted individually. ${ }^{35}$ Thus the single-subject rule protects voters from inuplicitly approving laws or constitutional amendments of whicis they are unaware, or of which they disapprove, in pursuit of others which they desire.

In Califormia, the requirment that legislation be confined to one subject actually predates the initiative process; it has applied since

32. In some states, the constitutional language directly states that no mitiative measure may contain more than one subject. E.g., CAL. CONST. art. II, \&8(d). Other states require each amendmeut to be voted on separately. Thus a petition that imcludes more than one subject is considered to be two measures voted on together, in violation of this provision. See, e.g., ARIz. CoNsT. art. XXI, \&1.

An analagous requirement applies to legislation generally, and thus may include initiative statutes. See, e.g., CAL. Const. art. IV, $\S 9$. Whether or not other constitutional provisions directed at legislation generally apply to initiative legislation in particular remains undecided. See Brosnahan v. Brown, 32 Cal. 3d at 282-84 nn.13-14, 651 P.2d at 302-04 nn.13-14, 186 Cal. Rptr. at 58-60 nn.13-14 (Bird, C.J., dissenting) (discussing requirement that amended statutes must be fully set out as amended). See also Ruud, "No Law Shall Embrace More than One Subject", 42 Minn. L. Rev. 389 (1958) (single-subject rule as applied to the legislature).

33. Amador Valley Joint Union High Scliool Dist. v. State Bd. of Equalization, $22 \mathrm{Cal}$. 3d 208, 231, 583 P.2d 1281, 1291, 149 Cal. Rptr. 239, 249 (1978); In re Initiative Petition No. 314, 625 P.2d 595, 603 (Okla. 1981). See generally State ex rel. Jones v. Charboneau's, 27 Wash. App. 5, 615 P.2d 1321 (1980).

34. The "shorthand" title may be the one provided by state officials, see supra notes $25-27$ and accompanying text, by the initiative measure itself, see Proposition $8, \S 1,1982$ Cal. Legis. Serv. 1164, 1164 (West) ("This amendment shall be known as 'The Victims' Bill of Rights'."), reprinted in Brosnahan v. Brown, 32 Cal. 3d 236, 300, 651 P.2d 274, 314, 186 Cal. Rptr. 30, 70 (1982) (appendix to dissenting opinion of Bird, C.J.), or through the campaign process, see Note, The California Initiative Process:" A Suggestion for Reform, 48 S. CAL. L. REv. 922, 937-38 (1975).

35. See Kerby v. Luhrs, 44 Ariz. 208, 214-15, 36 P.2d 549, 551-52 (1934); Brosnahan v. Brown, 32 Cal. 3d at 250,651 P.2d at 282, 186 Cal. Rptr. at 38. Note that only inuphicit logrolling is prevented. Explicit logrolling-the trading of votes on measures separately subunitted-is not prevented by the single-subject rule. Ruud, supra note 32 , at 448-49. Initiative ineasures are particularly vulnerable to logrolling, because there is little or no opportunity for coinpromise before the measure is drafted. Thus, the compromises to be made, if any, will be left to the voters. Note, supra note 9, at 456-57; Note, Initiative and Referendum-Do They Encourage or Impair Better State Government?, 5 FLA. ST. U.L. REV. 925, 948-49 (1977); Note, supra note 34, at 933. 
statehood. ${ }^{36}$ The rule did not apply to initiative ineasures until a constitutional amendment, submitted by the legislature, was adopted at the 1948 general election. ${ }^{37}$

The Cahfornia Suprene Court held this restriction to be identical when apphied either to initiative measures or to acts of the legislature. ${ }^{38}$ The court already had liberally interpreted the requirement for legislative acts. In Evans $v$. Superior Court, ${ }^{39}$ the enactment of the Probate Code as a smgle piece of legislation was challenged. The court held that even though the code contained soine 1700 different sections, it constituted one subject. ${ }^{40}$ The opinion noted that legislation would be upheld if all of its parts were "reasonably gerniane" to a single subject. ${ }^{41}$

Subsequent cases applying the single-subject requirement to mitiatives inconsistently applied various tests while reaching increasingly liberal results. A "functional relationship" test, stricter than the reasonably germane test, was referred to in Amador Valley Joint Union High School District v. State Board of Equalization, ${ }^{42}$ an unsuccessful single-subject challenge to Proposition $13 .{ }^{43}$ However, the plurality in Fair Political Practices Commission v. Superior Court, ${ }^{44}$ in upholding the Political Reforn Act of $1974,{ }^{45}$ refused to apply that test. ${ }^{46}$ It was

36. CAL. CONST. of 1849 , art. IV, $\& 25$ (currently CAL. Const. art. IV, \& 9).

37. The ballot pamphlet advised voters that the single-subject restriction would "simplif[y] and clarif[y] [the] issues presented to the voters" by "limit[img] each proposed amendment to one subject and oue subject only." California Secretary of State, Proposed Amendments to Constirution 8 (General Election Nov. 2, 1948). The argument im favor of the proposed singlesubject requirement also noted that it would make California's constitution a "more comprehensible and understandable" document. Id. at 9.

38. In Perry v. Jordan, 34 Cal. 2d 87, 207 P.2d 47 (1949), the court held that the same meaning was intended by both these single-subject requirements. $I d$. at 93, 207 P.2d at 50 .

39. 215 Cal. 58, 8 P.2d 467 (1932).

40. Id at $62-63,8$ P.2d at 469 .

41. Id. Alternatively, the court held that if the legislation's parts were "so related and intcrdependent as to constitute a single scheme," the legislation would be upheld. The "related and interdependent" language was the subject of more detailed exaunination in Brosnahon v. Brown, where the court ultimately dismissed it as dictum. 32 Cal. 3d 236, 249, 651 P.2d 274, 281, 186 Cal. Rptr. 30, 37 (1982).

42. 22 Cal. 3d 208, 230, 583 P.2d 1281, 1290, 149 Cal. Rptr. 239, 248 (1978) (quoting Schmitz v. Younger, 21 Cal. 3d 90, 100, 577 P.2d 652, 657-58, 145 Cal. Rptr. 517, 522-23 (1978) (Manuel, J., dissenting)).

43. CAL. CONST, art. XIIIA. The amendment limited both the assessed valuation and percentage levy of ad valorein real property taxes, $i d . \S 1$, and provided for a maximuin two percent annual increase in this fixed amount, $i d$. $\$ 2$. In addition, new "special taxes" at the local levcl were prohibited absent two-thirds voter approval, $i d$. $\$ 4$, and new state taxes were prohibited absent two-thirds approval in the legislature, $i d . \S 3$.

44. 25 Cal. 3d 33, 599 P.2d 46, 157 Cal. Rptr. 855 (1978), cert. denied, 444 U.S. 1049 (1980).

45. This initiative statute's many provisions mcluded limits on cainpaign spending, regulation of lobbyist activities, and rules for preparing the ballot pamphlet. CAL. Gov'T CODE $\$ \$ 81000-91014$ (West 1976 \& Supp. 1983). Since enactment in 1974, several sections of the Act have been held in violation of the first amendment. See Fair Political Practices Comm'n, 25 Cal. 3d at 38, 599 P.2d at 48,157 Cal. Rptr. at 857. 
not until Brosnahan v. Brown ${ }^{47}$ that the court finally settled on the reasonably germane test. In that case, the majority determined that Proposition 8 's disparate provisions ${ }^{48}$ were reasonably germane to each other and to the general object of furthering the rights of actual or potential crime victims. ${ }^{49}$ While the precise parameters of the reasonably germane test remain uncertam, the court has emphasized that the test is to be broadly and liberally construed. ${ }^{50}$ As a result, the court has stretched the test to allow broader and more ambitious initiatives to fit within its parameters. ${ }^{51}$

\section{The Nonrevision Requirement}

Most state constitutions require constitutional revisions to be submitted either by the legislature or by a constitutional convention, ${ }^{52}$ and hence not by initiative. ${ }^{53}$ This nonrevision requirement does not apply to imitiative statutes, however. Some states permit recodification of statutes-even revision of an entire body of law-in a single measure. ${ }^{54}$ In contrast to the single-subject requirement, which is intended only to protect the voters from confusion and deception, the nonrevision re-

46. Fair Political Practices Comm'n, 25 Cal. 3d at 50, 599 P.2d at 50, 157 Cal. Rptr. at 859 (plurality opinion).

47. 32 Cal. 3d 236, 651 P.2d 274, 186 Cal. Rptr. 30 (1982).

48. Proposition 8 affects virtually every phase of criminal proceedings. New pretrial rules include consideration of public safety in setting bail and abolition of plea bargaining in serious felony cases. At trial, all relevant evidence is admissible (with only three exceptions) unless privileged, prior convictions can be used without hmitation for impeachment, the defense of dininished capacity is abolished, and that of insanity strictly limited. At sentencing, enhanceinents are provided for prior serious felony convictions, victims are allowed to testify and the judge inust respond to their testimony in setting sentence, and no person over 18 convicted of a serious felony may be committed to the Youth Authority. After trial, victims are entitled to testify at parole hearings, and to receive restitution from the person(s) convicted. The measure also establishes a general right of safety in pubhic schools. See id. at 242-45, 651 P.2d at 277-79, 186 Cal. Rptr. at 3335.

49. Id. at 247, 651 P.2d at 280, 186 Cal. Rptr. at 36. The court treated the plurahity opinion in Fair Political Practices Comm'n as controlling. Id. at 250, 651 P.2d at 282, 186 Cal. Rptr. at 38.

50. Id. at 262, 651 P.2d at 289, 186 Cal. Rptr. at 45 (quoting Associated Homebuilders v. City of Livermore, 18 Cal. 3d 582, 591,557 P.2d 473, 477, 135 Cal. Rptr. 41, 45 (1976)). See also Massachusetts Teachers Ass'n v. Secretary of the Commonwealth, 1981 Mass. Adv. Sli. 1764, 424 N.E.2d 469 (upholding initiative statute, "Proposition 21/2," against single-subject challenge).

51. In 1978, the court upheld the Political Reforun Act, see supra note 45 and accoinpanying text, and Proposition 13, see supra note 43 and accoinpanying text. In 1982, the court upheld Proposition 8. See supra note 48 and accompanying text.

52. E.g. CAL. CoNST. art. XVIII, §2. Solne states permit constitutional revision either by the legislature or by a convention specially called for that purpose. Others perunit revision only by the latter method. For a discussion of the different rules in different states, see Sinith v. Cenarrusa, 93 Idaho 818, 820-24, 475 P.2d 11, 13-17 (1970).

53. Amador Valley Joint Union High School Dist. v. State Bd. of Equalization, 22 Cal. 3d 208, 22I, 583 P.2d 1281, 1284, 149 Cal. Rptr. 239, 242 (1978).

54. See, e.g., UTAH Const. art. VI, § 22; Evans v. Superior Court, 215 Cal. 58, 8 P.2d 467 (1932). 
quirement additionally ${ }^{55}$ is based on the theory that comprehensive changes $\mathrm{m}$ the state's fundamental law require more discussion and deliberation than is available through the initiative process. ${ }^{56}$ Thus, even the most simple and clearly worded initiative constitutional amendment iniglit constitute an impermissible revision. ${ }^{57}$

In California, early cases established that inappropriate ${ }^{58}$ or extensive $e^{59}$ changes in the constitution could constitute a revision. More recently, the court lias incorporated these principles into a quantitativequalitative test. ${ }^{60}$ Thus, an initiative constitutional amendment that changes the "substantial entirety" of the constitution or fundamentally alters "the nature of our basic governmental plan" could be an impermissible revision. ${ }^{61}$ No such revision has been found since $1948 .{ }^{62}$ Cases involving the nonrevision requirement in other states are rela-

55. Prevention of logrolling and voter confusion are implicit policies of the nonrevision requirement. A revision is as likely to result in logrolling and voter confusion as a multisubject amendment. In McFadden v. Jordan, 32 Cal. 2d 330, 346, 196 P.2d 787, 797 (1948), cert. denied, 336 U.S. 918 (1949), discussed at infra note 59, the court discussed logrolling and voter confusion as grounds for striking down the amendinent as an impermissible revision.

56. "[R]evision contemplates deliberative action of either the Legislature or a convention duly assembled in order to accomplish harmony im language and purpose between articles and to produce as nearly as possible a document free of doubts and inconsistencies." Adams v. Guntcr, 238 So. 2d 824, 829 (Fla. 1970). Cf. Schmitz v. Younger, 21 Cal. 3d 90, 100, 577 P.2d 652, 657, 145 Cal. Rptr. 517, 522 (1978) (Manuel, J., dissenting) (single-subject rule necessary because voters cannot examine proposals as closely as legislators).

57. "[A]n enactment which purported to vest all judicial power in the Legislature would amount to a revision without regard either to the length or coinplexity of the measure or the number of existing articles or sections affected by such change." Ainador Valley Jomt Union High School Dist. v. State Bd. of Equalization, 22 Cal. 3d 208, 223, 583 P.2d 1281, 1286, 149 Cal. Rptr. 239, 244 (1978) (dictum). See Adams v. Gunter, 238 So. $2 d 824$ (Fla. 1970) (initiative constitutional ameudment held invalid on this ground), discussed at infra note 64 .

58. See Livermore v. Waite, 102 Cal. 113, 118, 36 P. 424, 426 (1894). The doctrine that constitutional amendments submitted either by initiative or by the legislature could be invalidated if they were "fundamentally statutory" in character was used in earlier cases, but has been rejected in modern litigation. See Note, supra note 35, at 944.

59. In McFadden v. Jordan, 32 Cal. 2d 330, 196 P.2d 787 (1948), cert. denied, 336 U.S. 918 (1949), the court enjoined the vote on an imititative constitutional amendment which would have repealed and replaced the bulk of the Califorma Constitution. Although there was no singlesubject requirement for initiatives at the time, the court held that the provisions were so extensive as to constitute an impermissible revision. Id. at 345-46, 196 P.2d at 796.

The adoption in 1948 of the simgle-subject requirement for imitiatives has been recognized as a response to the type of initiative struck down in McFadden. Brosnalian v. Brown, 32 Cal. 3d 236, 267-68, 651 P.2d 274, 293, 186 Cal. Rptr. 30, 49 (1982) (Bird, C.J., dissenting); Comment, supra note 8 , at 1722 n.32.

60. Amador Valley Joint Union High Sclıool Dist. v. State Bd. of Equatization, 22 Cal. 3d 208, 223, 583 P.2d 1281, 1286, 149 Cal. Rptr. 239, 244 (1978).

61. Id.

62. For cases upholding an imitiative constitutional amendment agaimst a nonrevision challenge, see id. at 224-29, 583 P.2d at 1286-89, 149 Cal. Rptr. at 244-47 (upholding CAL. CoNst. art. XIIIA). See also Brosnalian v. Brown, 32 Cal. 3d 236, 260-61, 651 P.2d 274, 288-89, 186 Cal. Rptr. 30, 44-45 (1982) (upholding CAL. Const. art. 1, § 28); People v. Fricrson, 25 Cal. 3d 142, 187, 599 P.2d 587, 614, 158 Cal. Rptr. 281, 307 (1979) (upholding CAL. Const. art. I, § 27). For a discussion of McFadden $v$. Jordan, in which a revision was found, see supra note 59. 
tively infrequent, ${ }^{63}$ but the rule apphed is similar to California's. ${ }^{64}$

II

\section{TIMING OF REVIEW}

The standards of judicial review described above are related to the procedural context in which challenges are brought. The process of initiative qualification can be divided into three periods: the time between the submission of the proposed imitiative to state officials ${ }^{65}$ and the return of the petitions for collection of signatures (the precirculation period); the time between circulation and the submission of the qualified initiative to the voters (the preelection period); and the postelection period.

\section{A. Precirculation Review}

Before the initiative measures are circulated for signatures, review is restricted to compliance with statutory requirements regarding the forn of the petitions and the titles and summaries for the measures. Courts have held that state officials cannot go beyond these statutory

63. Challenges more typically involve substantive limitations. See infra note 64. See, e.g., Boucher v. Engstrom, 528 P.2d 456 (Alaska 1974) (initiative statute may not enact local or special legislation, measure upheld in preelection litigation); Bowe v. Secretary of the Commonwealth, 320 Mass. 230, 69 N.E.2d 115 (1946) (initiative measure may not amend provisions governing freedom of speech and assembly, measure invalidated in preelection litigation).

64. See, e.g., Adams v. Gunter, 238 So. 2d 824, 829-30 (Fla. 1970) (initiative constitutional amendment providing for a unicameral legislature constituted inupermissible revision). In 1972, Florida's Constitution was amended to permit revision by initiative, thus overruling Adams. See FlA. Const. art. XI, §3. Florida is apparently the only state where revision by initiative is permitted, but the simgle-subject requirement still applies. Floridians Agamst Casino Takeover v. Let's Help Florida, 363 So. 2d 337 (Fla. 1978).

There are various other restrictions on the use of the initiative. Initiatives cannot override federal law or supreme state law. Fair Political Practices Comm'n v. Califomia State Personnel Bd., 77 Cal. App. 3d 52, 56, 143 Cal. Rptr. 393, 396 (1978). Initiative constitutional amendments are similarly subordinate to federal law. See supra note 5 . Additionally, many states prohibit appropriation by initiative. E.g. ALASKA CoNST. art. XI, § 7; Mo. CoNST. art. III, § 51; NEB. REV. STAT. \$ 32-704.01 (1978). Analagous provisions in the District of Columbia were held applicable to a referendum petition, and the petition invalidated. Convention Center Referendum Comm. $v$. District of Columbia Bd. of Elections and Ethics, 441 A.2d 889, $911-16$ (D.C. 1981). Other states prohibit amendment of provisions of the state's "Bill of Rights" or other specific constitutional provisions. E.g. MASs. Const. amend. art. 48, Init., pt. 2, \$2. Finally, states may bar the resubmission of a defeated imitiative measure for a certam number of years. E.g. , id. $\$ 3$ (three years); OKLA. CONST. art. V, $\S 6$ (any such petition must bear signatures of $25 \%$ of the state's legal voters, as compared to the ordinary requirement of $15 \%$ of the votes cast in the prior election, id. $\S 2$, if the measure was submitted within the past three years). Like the nonrevision requirement, these restrictions are not based solely on voter protection, but recognize that even direct democracy has its limitations. See, e.g., Note, Constitutional Constraints on Initiative and Referendum, 32 VAND. L. REV. 1143 (1979) (Because the initiative is a form of democratic rather than republican government, courts must guard against derogation by the majority of individual rights and liberties.).

65. In states where precirculation approval of initiative petitions is not required, there would be no reviewable precirculation "action." 
duties $^{66}$ to question the merits of the initiative at this stage. ${ }^{67}$ Thus, the only permissible action reviewable by the courts relates to these technical rules.

\section{B. Preelection Review}

Once petitions have been circulated and submitted to the Secretary of State for verification, opponents of an initiative measure have ammumition for their attack. ${ }^{68}$ Comphance with form, signature, and title and summary requirements are then at issue. All states have held that review of these requirements is available prior to the election, but California permits both preelection and postelection review of these requirements. ${ }^{69}$

In many states, comphance with the smgle-subject and nonrevision requirements is also reviewable prior to the election. ${ }^{70}$ Cahfornia,

66. See supra text accompanymg note 10.

67. Schmitz v. Younger, 21 Cal. 3d 90, 92-93, 577 P.2d 652, 653, 145 Cal. Rptr. 517, 518 (1978) (Attorney General has no power to refuse to provide a title and summary for an initiative because of its doubtful constitutionality); accord City of Rocky Ford v. Brown, 133 Colo. 262, 265, 293 P.2d 974, 976 (1956); see also State ex rel. Carter v. Celebrezze, 63 Ohio St. 2d 326, 329-30, 410 N.E.2d 1249, 1251 (1980) (W. Brown, J., concurring) (Secretary of State has no authority to disregard typographical errors on petitions). But see White v. Welling, 89 Utah 335, 341, 57 P.2d 703, 705 (1936) (limited circumstances under which Secretary of State may declare petitions invalid). But there are a number of decisions made prior to the election which do involve a certain amount of discretion, such as providing a title and summary for the measure, preparing a ballot pamphlet, and selecting arguments for and agamst cach measure. See infra note 93.

68. No opponents of initiative measures were involved in the precirculation cases discussed at supra note 67 . In all four cases, the initiatives' proponents brought mandamus actions against the state official.

69. See, e.g., Assembly of California v. Deukmejian, 30 Cal. 3d 638, 639 P.2d 939, 180 Cal. Rptr. 297 (referendum petitions), appeal dismissed and cert. denied, 456 U.S. 941 (1982).

This can be a two-edged sword; in inost states except California, see infra text accompanying note 78, the grant of preelection review of these requirements also precludes postelection review. See, e.g., State ex rel. Schwartz v. Brown, 32 Ohio St. 2d 4, 10, 288 N.E.2d 821, 825-26 (1972) (enforcing Ohıо CoNST. art. II, $\S \mathrm{lg}$; such suits inust be brought 40 days before the election). Many states specify short statutes of limitations for these actions. See, e.g., ME. REV. STAT, ANN. tit. 21, § 1355(2) (Supp. 1982) (five days).

In addition, some states require these actions to be brought prior to the certification of the measure for the ballot. See, e.g., Renck v. Superior Court, 66 Ariz. 320, 187 P.2d 65 (1947); Cope v. Toronto, 8 Utah 2d 255, 258, 332 P.2d 977, 979 (1958); N.D. CoNST. art. III, § 7.

70. See, e.g., Kerby v. Luhrs, 44 Ariz. 208, 36 P.2d 549 (1934); Floridians Against Casino Takeover v. Let's Help Florida, 363 So. 2d 337, $339-40$ (Fla. 1978); Coalition for Political Honcsty v. State Bd. of Elections, 83 Ill. 2d 236, 253-60, 415 N.E.2d 368, 378-82 (1980); Massachusetts Teachers Ass'n v. Secretary of the Commonwealth, 1981 Mass. Adv. Sh. 1764, 1786 n.19, 424 N.E.2d 469, 482 n.19 (dictum) (postelection case); In re Initiative Petition No. 314, 625 P.2d 595 (Okla. 1981).

In Alaska, the single-subject requirement may be treated as a procedural rule, reviewable only in preelection litigation. ALASKA STAT. $\$ 15.45 .040$ (1982) specifies the "form" of an initiative bill: it must contain only one subject, which must be expressed in its title, and must contain an enacting clause. These and any other challenges to "form," $i d . \$ 15.45 .010$ (1982) (no mitiative may dedicate revenues, make appropriations, create courts, or enact local or special legislation), are reviewable prior to the election, Boucher v. Engstrom, 528 P.2d 456, 460 (Alaska 1974), and 
however, departs from this norm. In California, review of the singlesubject requirement before the election is precluded, absent a "clear showing of invahdity."71 Preelection review of compliance with the nonrevision requirement is similarly precluded, ${ }^{72}$ although in $\mathrm{McFad}$ den $v$. Jordan ${ }^{73}$ the nonrevision requirenent was reviewed in preelection litigation. ${ }^{74}$

\section{Postelection Review}

Once the electors have approved the measure, ${ }^{75}$ the willingness of the courts to review challenges based on form, signature, and title and summary requirements differs among the states. Most states either place a much higher burden of proof on challengers, ${ }^{76}$ or preclude review altogether. ${ }^{77}$ California does not explicitly bar any challenges af-

are not reviewable after the election, ALASKa STAT. $\$ 15.45 .230$ (1982). Ohio may also have this rule, but the authority is less clear. In State ex rel. Schwartz v. Brown, 32 Ohio St. 2d 4, 10, 288 N.E.2d 821, 825-26 (1972), the court held the limitation of actions, see supra note 69, "extends to any defect of the petition of such character as would render it insufficient to require submission to a vote of the electorate," but empliasized that this extends only to the petitions. The court did not indicate whether a simgle-subject violation would be encompassed in the "petitions" or in the ineasure itself. However, the likely inference is that postelection review would not be precluded.

71. Brosnahan v. Eu, 31 Cal. 3d 1, 4, 641 P.2d 200, 201, 181 Cal. Rptr. 100, 101 (1982) (preelection challenge based on alleged simgle-subject violation not reached). See also Schmitz v. Younger, 21 Cal. 3d 90, 92-93, 577 P.2d 652, 653, 145 Cal. Rptr. 517, 518 (1978). Accord Beechnau v. Secretary of State, 42 Mich. App. 328, 331, 201 N.W.2d 699, 701 (1972) ("[T]his Court will not pass upon the constitutionality [single-subject cluallenge] of a proposed law before it is submitted to the people."). Missouri has a similar rule, although its current status is im doubt. In Moore v. Brown, 350 Mo. 256, 267, 165 S.W.2d 657, 662 (1942), the court lield that the single-subject requirement is substantive; if it is violated, the measure is void from the beginning, and preelection relief is unnecessary. However, in Buclianan v. Kirkpatrick, 615 S.W.2d 6, 12-13 (Mo. 1981), the court noted in dictum that the single-subject requirement would be reviewable prior to the election. Thus, the standing of the Moore rule is nnclear.

72. Brosnahan v. Eu, 31 Cal. 3d at 4, 641 P.2d at 201, 181 Cal. Rptr. at 101.

73. 32 Cal. 2d 330, 196 P.2d 797 (1948), cert. denied, 336 U.S. 918 (1949), discussed at supra note 59.

74. McFadden may have involved the kind of "clear showing of invalidity" required by Brosnahan v. Eu, $31 \mathrm{Cal}$. 3d at 4,641 P.2d at 201, 181 Cal. Rptr. at 101. If not, McFadden may have been overruled on this point. The result in Brosnahan v. $E u$ is similar to that under Moore v. Brown, 350 Mo. 256, 165 S.W.2d 657 (1942), discussed at supra note 71, where preelection review was not held to be strictly unavailable, but only "unnecessary".

75. If the measure is defeated, the challenges are moot. See Dorman v. Young, 80 Idaho 435, 332 P.2d 480 (1958).

76. For example, states which allow postelection review of compliance with form, signature, and title and summary requirements may require a showing that the alleged violations misled a substantial number of voters-a difficult showing to make. See Comment, Judicial Review of Initiative Constitutional Amendments, 14 U.C.D. L. REv. 461, 481 (1980). In Massachusetts Teachers Ass'n v. Secretary of the Commonwealth, 1981 Mass. Adv. Sll. 1764, 1785-86, 424 N.E.2d 469, 482 , the court noted that only "fnndamental procedural and substantive requirements" will be subject to postelection review.

77. This result is obtamed in some states from express constitutional language, see, e.g. , ARK. Const. amend. 7; N.D. ConsT. art. III, $\S 6$; OHIO CoNST. art. II, $\S \mathrm{Ig}$, and im otlier states by application of the doctrine that an election cures all procedural defects, see, e.g., Renck v. Superior Court, 66 Ariz. 320, 187 P.2d 656 (1947). 
ter the election. In California, the sufficiency of titles and summaries has been reviewed after the election, and the courts have given no indication that this review is in any way restricted. ${ }^{78}$

A majority of states allow postelection review of comphance with the single-subject rule, ${ }^{79}$ and apparently states with a nonrevision requirement will hear challenges on that basis after the election. ${ }^{80}$ The difference between these two requirements which inost courts outside California will review after the election, and the form, signature, and title and summary requirements, which most courts will not then review, is difficult to characterize. Some states have adopted a procedural-substantive distinction. ${ }^{81}$ The form, signature, and title and summary requireinents are categorized as procedural. The single-subject and nonrevision requireinents are substantive, protecting the voters and those affected by legislation once it is effective. Hence, the theory continues, the latter requirements are reviewable only after the election, ${ }^{82}$ as these substantive issues are more like federal constitutional objections, which courts uniformly recognize are not reviewable in preelection litigation. ${ }^{83}$

This distmction ignores important purposes of the single-subject and nonrevision rules. Both exist to ensure that voters are provided with clear and simple choices on the ballot-initiative ineasures that contain neither inultiple subjects with coinplex and undesirable tradeoffs nor substantial revisions of the constitutional scheme without benefit of thorough negotiation and debate. The next Part of this Coinment argues that these requirements are more like other procedural requirements, and therefore should be reviewable in California and other states prior to the election.

78. Brosnahan v. Brown, 32 Cal. 3d 236, 254, 651 P.2d 274, 284, 186 Cal. Rptr. 30, 40 (1982) (discussing title requirements as applied to initiative statute sections of Proposition 8); People v. Frierson, 25 Cal. 3d 142, 187, 599 P.2d 587, 614, 158 Cal. Rptr. 281, 308 (1979); Amador Valley Joint Union High School Dist. v. State Bd. of Equalization, 22 Cal. 3d 208, 242-44, 583 P.2d 1281, 1298-300, 149 Cal. Rptr. 239, 256-58 (1978).

79. See, e.g., Brosnahan v. Brown, 32 Cal. 3d 236, 651 P.2d 274, 186 Cal. Rptr. 30 (1982); Massachusetts Teachers Ass'n v. Secretary of the Commonwealth, 1981 Mass. Adv. Sh. 1764, 424 N.E.2d 469; Buchanan v. Kirkpatrick, 615 S.W.2d 6 (Mo. 1981). But see supra note 70 and accompanying text (states that might preclude postelection review).

80. See, e.g., School Dist. v. City of Pontiac, 262 Mich. 338, 345, 247 N.W. 474, 477 (1933).

81. See, e.g., Moore v. Brown, 350 Mo. 256, 268, 165 S.W.2d 657, 662 (1942), discussed at supra note 71.

82. Id. at 267,165 S.W.2d at 662 .

83. See, e.g., Grose v. Firestone, 422 So. $2 \mathrm{~d} 303,306$ (Fla. 1982) (constitutional amenciment submitted by legislature); Oklahonaans for Modern Alcoholic Beverage Controls, Inc. v. Shelton, 501 P.2d 1089, 1095 (Okla. 1972). But see Gayle v. Hamm, 25 Cal. App. 3d 250, 256-57, 101 Cal. Rptr. 628, 633-34 (1972) (suggesting that the court's "exercise of its equitable diseretion" would permit it to reach and decide constitutional issues before the election). 


\section{III}

\section{The Case for Preelection Review}

California's refusal to review compliance with the single-subject and nonrevision requirements until after the election ${ }^{84}$ threatens to invalidate desired legislation on the basis of defects that are readily curable. California's solution to the problem-lenient review of an initiative's compliance witl these requirements after the election-undermines the valuable voter protection intended by the requirements.

\section{A. Judicial Authority to Mandate Preelection Review}

There is no statutory or constitutional prohibition of preelection review of the single-subject and nonrevision requirements in Califormaa. $^{85}$ In fact, the constitutional amendment adding the single-subject requirement to the initiative process expresses a preference for preelection review in its statement that no inultisubject initiative "shall be subinitted to the electors." 86

Treating the single-subject, nonrevision, and other procedural requirements alike is more consistent doctrimally than treating the former as "substantive." The simgle-subject and nonrevision requirements are more like procedural requirements ${ }^{87}$ in that they are intended to protect the citizens in their involvement with the initiative process. ${ }^{88}$ They do not stand as general prohibitions on governmental powers, as do the federal constitutional requirements and their state law counterparts ${ }^{89}$

84. See supra note 71 (California cases precluding review of compliance with these requirements in preelection litigation).

85. Courts which refuse preelection review of the single-subject and nonrevision requirements have indicated that such refusal is discretionary. See, e.g., Gayle v. Hamm, 25 Cal. App. 3d 250, 256-57, 101 Cal. Rptr. 628, 633-34 (1972) (suggesting that court's "exercise of its equitable discretion" would permit it to reach and decide constitutional issues); Buchanan v. Kirkpatrick, 615 S.W.2d 6, 12-13 (Mo. 1981) (citing the single-subject and title and summary requirements, and noting that "[e]ither of these matters is reviewable by the courts prior to the election.").

86. CaL. Const. art. II, § 8(d). See Brosnahan v. Eu, 31 Cal. 3d 1, 7-8, 641 P.2d 200, 203, 181 Cal. Rptr. 100, 103 (1982) (Mosk, J., concurring and dissenting).

87. Bur see Schmitz v. Younger, 21 Cal. 3d 90, 92-93, 577 P.2d 652, 653, 145 Cal. Rptr. 517, 518 (1978) (arguing that these requirenents are substantive rather than procedural); Moore $\mathbf{v}$. Brown, 350 Mo. 256, 267, 165 S.w.2d 657, 662 (1942) (same).

This substance-procedure classificatiou does not accord with the various state schemes regulating the initiative process. Some states classify the single-subject rule as procedural. See supra note 70 . The review of the title of an initiative statute may involve both substantive and procedural considerations. See infra note 93 . Moreover, the designation of a certain provision as substantive or procedural does not necessarily suggest whether it should be reviewed after the election. "Why should a 'procedural' defect cry out for decision prior to enactunent of the measure when a 'substantive' one does not? The issue could be determined after a vote as easily in either case, and the same sort of egregious waste could be prevented by a prior decision." Comment, supro note 8 , at 1728 .

88. See supra notes 33-35 and accoinpanying text (single-subject requirement); supra note 55 and accoinpanying text (nonrevision requirement).

89. The interests mvolved are clearly differeut in the case of federal constitutional chal- 
that are reviewable only after the election.

Courts may be hesitant to engage in preelection review for many reasons. First, such review could frustrate the initiative process. Second, the court might decide cases that will become moot if the measure is defeated. Third, it is inefficient to make decisions on an incomplete record. On closer analysis, however, none of these are compelling reasons to deny preelection review. Preelection challenges would not thwart the initiative process any inore than would the same challenges if brought after the election. ${ }^{90}$ In addition, preelection challenges would not substantially imcrease courts' caseloads. ${ }^{91}$ Moreover, courts would have a fully developed record because a single-subject or nonrevision violation is discernible from the language of the initiative. ${ }^{92}$ Fimally, the completeness and finahty of the decision pose no problem in the form, signature, and title and summary cases already heard in preelection litigation. ${ }^{93}$

lenges, as demonstrated in Amador Valley Joint Union High School Dist. v. State Bd. of Equalization, 22 Cal. 3d 208, 583 P.2d 1281, 149 Cal. Rptr. 239 (1978), where challenges of both types were brought against CAL. Const. art. XIIIA (Proposition 13). Review of the single-subject and nonrevision requirements involved the interests of persons as voters and signers of the initiative. Id. at 22I, 231, 243, 583 P.2d at 1284, 1291, 1298, 149 Cal. Rptr. at 242, 249, 256. Review of the federal constitutional challenges involved the interests of persons as real property owners (equal protection), as residents or nonresidents of Cahfornia (right to travel), and as holders of state and local contractual obligations (impairment of contracts). Id. at 232, 237-38, 583 P.2d at 1292, 1295, 149 Cal. Rptr. at 250, 253.

90. Preelection review would constitute an additional inpediunent only if the court, in prcelection hitigation, wrongly invalidated a valid initiative. But that same risk obtains in postelection review; indeed "such risk taking is inherent in every legal prognostication and marks the very process by which law is practiced in this country . . . " Schmitz v. Younger, 21 Cal. 3d 90, 95. 577 P.2d 652, 654, 145 Cal. Rptr. 517, 519 (1978) (Manuel, J., dissenting).

91. Between 1970 and 1976, 104 initiatives were titled and circulated in California, but 87 failed to qualify for the ballot, and 13 more were rejected by the voters. REFERENDUMS, supro note 1 , at 91 . Furthermore, challengers are probably less likely to seek preelection review of a measure expected to be defeated at the polls.

92. If the court places great weight on the campaign to inform the voters and to removc confusion, see, e.g., Brosnahan v. Brown, 32 Cal. 3d 236, 252, 651 P.2d 274, 283-84, 186 Cal. Rptr. $30,39-40$ (1982), it inay be in a better position to examine the issues after the election. However, many commentators suggest that rehance on the campaign as a device to educate the voters is misplaced. REFERENDUMS, supra note 1, at 106-07; Note, supra note 34, at 937-39. The singlcsubject and nonrevision requirements are aimed at this problem; it is better to keep a potentially confusing and misleading measure off the ballot than to speculate after the election whcther the voters were confused or misled. Brosnahan v. Eu, 31 Cal. 3d 1, 8 n.2, 641 P.2d 200, 204 n.2, 181 Cal. Rptr. 100, 104 n.2 (1982) (Mosk, J., concurring and dissenting). And on this question, the court has a "full record" in preelection litigation. Id.; Schmitz v. Younger, 21 Cal. 3d 90, 96, 577 P.2d 652, 655, 145 Cal. Rptr. 517, 520 (1978) (Manuel, J., dissenting) (implying that the measure is record enough, and refusing to rely on election publicity).

93. Issues already raised in preelection cases indicate that courts currently review significant issues. The title and summary and ballot pauphlet inaterial can be extremely important to an initiative's success. Note, supra note 34, at $930 \mathrm{n.47}$ ("[W] hile the title has no legal effect if the proposal is enacted, it may have political impact. For example, there is a political advantage to 


\section{B. Disadvantages of Postelection Review}

Invalidation of an initiative after it has passed works a hardship both upon its proponents and its opponents. Substantial sums are spent placing an initiative on the ballot and advocating its passage or defeat. ${ }^{94}$ If the initiative is invalidated, all these expenditures nay be repeated if the proponents then want to redraft and resubinit the measure. By deciding the issue after the election, the court deprives the proponents of a chance to reinedy their errors. When a preelection challenge is to the title and summary or the manner of certification, the Attorney General or Secretary of State can cure the defect prior to the election. ${ }^{95}$ Similarly, if a preelection challenge is permitted based on the single-subject or nonrevision requirements, the proponents would have an opportunity to redraft their initiative neasure in compliance with these requirements. ${ }^{96}$

Postelection invalidation creates other hardships as well. The voters may be temporarily or permanently denied the beneficial effects of the initiative they passed. Thus the court arguably frustrates the "will of the voters," even though the premise of most of the requirenients is that the voters must be protected froin deception and confusion. Moreover, there are institutional costs to invalidation. Initiatives often involve hotly contested pohtical matters. ${ }^{97}$ Interference by the court after

the title 'Clean Environmeut Act' over 'Pollution Initiative.' "); Comment, supra note 5, at 461-64 (criticizing use of administrative discretion in providing access to ballot pamphlets).

Even the verification of form and signatures, a function that appears "ministerial," involves conflicts arising from the official's exercise of judgment under the substantial coinphance doctrine. See, e.g. , Asseinbly of California v. Deukmejian, 30 Cal. 3d 638, 639 P.2d 939, 180 Cal. Rptr. 297, appeal dismissed and cert. denied, 456 U.S. 941 (1982), discussed at supra notes 23-24 and accompanying text; State ex rel. Carter v. Celebrezze, 63 Ohio St. 2d 326, 410 N.E.2d 1249 (1980), noted in 15 AKRON L. REV. 157 (1981) (discussing and denying the Secretary of State power to ignore printer's error on initiative petitions); Thomson v. Wyoning In-Stream Flow Comm., 651 P.2d 778, 786 (Wyo. 1982) (noting that "[i]f the Secretary's acts were discretionary, she and her staff went out of their way to exercise discretion in favor of [proponents]").

But see Brosnahan v. Eu, 31 Cal. 3d at 5, 641 P.2d at 202, 181 Cal. Rptr. at 102 (Broussard, J., concurring) ("Time is lacking for the careful study and consideration, the collegial discussion, and the mutual criticism of opinion drafts which an issue of this importance requires."); id. at 14, 641 P.2d at 207, 181 Cal. Rptr. at 107 (Bird, C.J., dissenting) (noting fear that "the tremendons time pressure surrounding this case has forced this court to set down a precedent that may return one day to haunt us").

94. REFERENDUMS, supra note 1 , at 104-06 (listing amounts ranging froin $\$ 60,000$ to $\$ 3.8$ million spent on California initiative campaigns in the 1972-1976 period); Note, supra note 34, at 939-40.

95. See, for example, Brosnahan v. Eu, 31 Cal. 3d 1, 641 P.2d 200, 181 Cal. Rptr. 100 (1982), where just such an issue was hitigated prior to the election. If the Secretary of State had decided to certify signatures individually rather than by randoin sample, the proponents would not have quahified their measure for the June 1982 primary election. See supra note 20.

96. See Brosnahan v. Eu, 31 Cal. 3d at 16, 641 P.2d at 209, 181 Cal. Rptr. at 209 (Bird, C.J., dissenting).

97. Comment, supra note 76 , at 463 n.12; Note, supra note 9, at 429 . 
the election may diminish the public's respect for the judiciary. ${ }^{98}$ Courts avoid these hardships of invahidation by making their postelection compliance standards overly heral. ${ }^{99}$ But such cursory review may frustrate the important purposes of these imitiative regulations.

The California Supreme Court's hiberal postelection review of comphance with the single-subject requirement also undermines its purpose. First, the court presumes that the voters were well-inforned, were not misled, and understood the measure. ${ }^{100}$ But because the single-subject requirement is intended to protect the voters, the court begs the question when it begins its analysis by assuning the voters do not need protection. ${ }^{101}$ Second, the court rarely engages im principled analysis in this area. While often debating the nature of the tests applied, ${ }^{102}$ the court has allowed progressively broader initiatives to fit within the parameters of the requirement. ${ }^{103}$ The reasonably germane test adopted in Brosnahan v. Brown ${ }^{104}$ appears to be no more than a reasonableness test, as if the issue were to be decided by a jury. ${ }^{105}$ And those "jurors" unfailingly capitulate to the voters' approval of an mitiative. ${ }^{106}$

An example of the court's approach to postelection review of the single-subject requirement is Brosnahan v. Brown. There, the subject to which Proposition 8's provisions were held to be reasonably germane-

98. "Since the initiative system originated in response to public distrust of legislatures, it is ironic that renewed and exacerbated distrust of government might now be aimed at the judiciary if popular initiative proposals are invahidated." Comment, supra note 5, at 435. See also id. at 435 n.13 (noting threats of recall and "physical harm" directed at California Supreme Court justices as they prepared to hear arguments on the validity of Proposition 13 after its approval at the June 1978 election).

99. See supra notes 76-77 and accompanying text.

100. Brosnahan v. Brown, 32 Cal. 3d at 252, 651 P.2d at 283-84, 186 Cal. Rptr. at 39.40 (quoting Amador Valley, 22 Cal. 3d at 243-44, 583 P.2d at 1298-99, 149 Cal. Rptr. at 256-57).

101. "It seems self-evident that [the objective of preventing voter deception or confusion] will be violated by allowing the electorate to vote on a measure which inay be misleading, since the [single-subject] requirement is designed precisely to avoid that result." Brosnahan v. Eu, 31 Cal. 3d 1, 7, 641 P.2d 200, 203, 181 Cal. Rptr. 100, 103 (1982) (Mosk, J., concurring and dissenting). See also Buchanan v. Kirkpatrick, 615 S.W.2d 6, 21 (Mo. 1981) (Rendlen, J., dissenting) (presuming validity of amendment in postelection case "improperly penalizes appellants in the quest for [preelection] adjudication of their claims . . ..").

102. See supra notes $\mathbf{4 2 . 4 9}$ and accompanying text.

103. See supra note 51 .

104. 32 Cal. 3d 236, 245, 651 P.2d 274, 279, 186 Cal. Rptr. 30, 35 (1982).

105. Four nembers considered the initiative "reasonable," id. at 247, 651 P.2d at 280, 186 Cal. Rptr. at 36 ("it is readily apparent that Proposition 8 meets the 'reasonably germane' standard"), and three did not, id. at 273, 651 P.2d at 296, 186 Cal. Rptr. at 52 (Bird, C.J., dissenting) ("[i]f this court were to accept such an expansive definition of a single subject, initiativcs could einbrace hundreds of uncounected statutes").

106. See, e.g., Ruud, supra note 32, at 447 ("This seems to justify courthouse lorc to the effect that an argument based on the one subject rule is often the argument of a desperate advocate who lacks a sufficiently sound and persuasive one."). 
"promoting the rights of actual or potential crime victims"107-was created im postelection litigation, and differed substantially from previously proposed subjects. ${ }^{108}$ Moreover, the court never discussed how its interpretation of the single-subject requirement could prevent voter confusion or logrolling. Indeed, both the majority ${ }^{109}$ and one dissent ${ }^{110}$ discussed the issues of voter confusion and logrolling separately from the reasonably germane test, as if the former somehow constitute independent grounds to invalidate an initiative. ${ }^{11}$

Courts have been similarly lenient in their postelection review of comphance with the nonrevision requirement. The quantitative-qualitative analysis used in California has permitted extensive reforms through the initiative. ${ }^{112}$ Because the nonrevision requirenient, like the single-subject requirement, is in part intended to prevent voter confusion and deception, ${ }^{113}$ voters may be denied the protection that this requirement is intended to provide. ${ }^{114}$

The postelection review currently available in Califorma is, in short, illusory. Such uniforn belated capitulation to the voters does httle to ensure that the public is provided with clearly and objectively described single-subject initiatives. It would be wiser for the courts to develop effective standards to be applied before the election.

\section{Advantages of Preelection Review}

Preelection review furthers the interests of all participants in the initiative process. Violations of imitiative requirements, if spotted at the preelection stage, often could be readily cured. Then the voters could be presented at the scheduled election with clear, understandable initiatives comprising only one subject. If an initiative's defects were not curable, both its proponents and its opponents would be spared a substantial portion of the expenses associated with advocating or opposing an initiative. ${ }^{115}$ Finally, by undertaking review in the less politically

107. 32 Cal. 3d at 247, 651 P.2d at 280, $186 \mathrm{Cal}$. Rptr. at 36.

108. See id. at 273, 651 P.2d at 296, 186 Cal. Rptr. at 52 (Bird, C.J., dissenting) ("Apparently, [the Attorney General] has abandoned the proponents' earlier arguinent . . . that the single subject of this initiative is 'public safety.' ").

109. Id. at 250-52, 651 P.2d at 282-84, 186 Cal. Rptr. at 38-40.

110. Id. at 278-81, 651 P.2d at 300-01, 186 Cal. Rptr. at 56-57 (Bird, C.J., dissenting).

111. Justice Mosk, concurring and dissenting in Brosnahan v. Eu, 31 Cal. 3d 1, 641 P.2d 200, 181 Cal. Rptr. 100 (1982), the preelection case involving this same initiative ineasure, noted that "[o]nly if such a violation [of the single-subject rule] is found does the issue of voter confusion becoine relevant." Id. at 10, 641 P.2d at 205, 181 Cal. Rptr. at 105.

112. See supra note 62 .

113. See supra note 55 .

114. Even the other limitations on the scope of the initiative-which nay not be intended to protect the voters-are reviewed in preelection litigation. See cases cited supra note 63.

115. Some commentators, lowever, insist that even an unsuccessful initiative campaign nay be valuable. See REFERENDUMS, supra note 1, at 97; infra note 122. 
constraining environment before the election, courts could develop more effective doctrines of voter protection. Courts would ensure that initiative measures would be proper in form, scope, and subject matter. Then the voters' decision would be final. This would be the ultimate respect for the people's exercise of their initiative power.

\section{IV}

\section{A Proposal for Preelection Judicial Review}

For there to be effective review of compliance with form, signature, title and summary, single-subject, and nonrevision requirements, review must be undertaken before the election. The California Supreme Court already undertakes preelection review of forn, signature, and title and summary requirements, and could extend this review to implement the policies discussed above. ${ }^{116}$

Absent a sudden change in the court's policy, this Comment proposes legislative action to reach a similar result. The legislature is empowered by the Califorma Constitution to make reasonable regulations for the initiative process. ${ }^{117}$ This final Part of the Comment discusses the necessary elements of a statute establishing preelection review of initiatives. A proposed statute is set out in the Appendix. ${ }^{118}$

The proposed statute addresses several ancillary concerns. First, in order to avoid undue interference with the initiative process, preelection review should not suspend the proponents' ability to circulate petitions for signatures or to qualify the measure for the ballot. ${ }^{119}$ Second, preelection review should be mandatory in all cases where substantial doubt exists as to the measure's validity, ${ }^{120}$ thus effectively foreclosing postelection review. ${ }^{121}$ Third, to lower the costs of invalidation, review

116. See supra note 85 and accoinpanying text.

117. CAL. Const. art. II, \& 10(e).

118. The statute as proposed should be read in context with the surrounding current sections of the California Elections Code.

119. See Schmitz v. Younger, 21 Cal. 3d 90, 93, 577 P.2d 652, 653, 145 Cal. Rptr. 517, 518 (1978) ("[W]ithout prior judicial authorization [the Attorney General] nay not delay or inpede the initiative process while clains of the measure's invalidity are determined.").

Legislative regulation of constitutionally created rights and procedures is subject to the "selfexecuting" doctrine: the regulation must not unreasonably derogate the constitutional process. See, e.g., Coalition for Political Honesty v. State Bd. of Elections, 83 Ill. 2d 236, 250.53, 415 N.E.2d 368, $377-78$ (1980); Ferency v. Secretary of State, 409 Mich. 569, 590-96, 297 N.W.2d 544, $549-52$ (1980). Thus, although the legislature must be cautious of restricting the power of initiative, requiring preelection review probably would not be considered unreasonable or excessive legislative interference.

120. Preelection review is currently optional in every case, but the court in Brosnahan v. Eu indicated that this option will be refused in virtually all cases. 31 Cal. 3d 1, 4, 641 P.2d 200, 201, 181 Cal. Rptr. 100, 101 (1982) (requiring a "clear showing of invalidity"). The "substantial doubt" standard would be a significantly lower thresloold than the "clear showing of invalidity" required under Brosnahan v. Eu.

121. The preelection review would not stand as an explicit bar to litigation by opponents who 
should be expedited in the courts and be available to the citizens as early as possible in the initiative process. ${ }^{122}$ Thus, a prograin of preelection review must satisfy contradictory goals: It must provide meaningful and complete review, while not exacerbating the time pressures of imitiative qualification or election administration. ${ }^{123}$

The proposal set forth in the Appendix atteunpts to harmonize these goals. Preelection review is required in any case where there is substantial doubt of the initiative measure's validity. ${ }^{124}$ This determination is inade before the petitions are circulated, ${ }^{125}$ but judicial review is invoked only if the measure qualifies for the ballot. ${ }^{126}$ Provisions for expedited review ${ }^{127}$ minimize interference with the initiative process, in recognition of the crucial timing often involved in imitiative cam-

had no notice or opportunity to be heard in the preelection action. See Boncher v. Engstrom, 528 P.2d 456, 459 (Alaska 1974) (to be precluded from challenging ballot title, parties must be given notice of the preparation of the title); In re Ballot Title for Initiative 333, 88 Wash. 2d 192, 196, 558 P.2d 248, 250-51 (1977) (invalidating statute which would have limited review of a ballot title to an initiative's proponents). But as a practical inatter, stare decisis would govern the cases actually decided, and the "substantial doubt" standard would ensure that most cases in which a serious challenge could be made would be decided before the election.

Nonetheless, notice is provided in the proposed statnte in order that other interested persons might have an opportumity to intervene in the action. Notice is given in the petitions themselves, as suggested in Comment, supra note 8 , at $1725 \mathrm{n} .53$, and by publication once the action is initiated, according to the procedures of CAL. Gov'T CODE $\$ \S 6000-6075$ (West 1980). See Appendix $\S 3523.2(\mathrm{~b})$, infra p. 1237.

122. Once the initiative ineasure qualifies for the ballot, costs escalate rapidly as the election campaign begins. In addition, the timing of an initiative may be important in relation to a campaign for elective office, or as an educational and lobbying device. REFERENDUMS, supra note 1, at 99 . For some proponents, then, an initiative invalidated and postponed until the next election would be worthless. The earlier the review could take place, the better the chance that these defects can be removed and the proponents' intended schedule kept intact.

123. Note, supra note 9 , at 464.

124. See Appendix $\$ 3504.1$ (b), infra p. 1237. This determination is made by the Attorney General, who is to take into consideration the measure's potential for misleading, confusing, or deceiving the signers or voters. Id. $\$ 3504.1(\mathrm{e})$, infra p. 1237.

125. Id. $\$ 3504.1(\mathrm{a})$, infra p. 1237 . The proponents may redraft the measure if objectionable, or may circulate the petitions as originally intended. Thus, the preelection review gives the proponents notice of potential problems, but at the same time does not impede their ability to qualify the ineasnre. See Sclimitz v. Younger, 21 Cal. 3d 90, 577 P.2d 652, 145 Cal. Rptr. 517 (1978).

126. The judicial review mandated by Schmitz $v$. Younger is thus provided, but the court does not have to rule on the validity of measnres that umght never qualify for the ballot. Although this is relatively late in the initiative process, it provides review before inost of the expenditures have been made by proponents and opponents. See REFERENDUMS, supra note 1, at 101, 104 (listing 1972-1976 expenditnres in California initiative campaigns ranging from $\$ 60,000$ to $\$ 3.8$ million, while those for circulation and qualification ranged from $\$ 9,000$ to $\$ 436,000$ ).

The procedure recommended in this statute is similar to that imvoked by a pnbhic agency, or by any interested party, to validate the actions of that agency. See CAL. Civ. Proc. CODE $\$ \$ 80$ 870 (West 1980).

127. See Appendix $\$ 3523.2(\mathrm{c})$, infra p. 1237-38. The language used here is patterued after CAL. ELEC. CODE § 10015 (West 1977) which provides for expedited review of alleged ballot errors. Such provisions for expedited review are used in other states. See, e.g., Colo. Rev. STAT. $\S \S 1-40-101(3),-102(3)$ (1980); WASH. REv. CODE ANN. $\$ \$ 29.79 .160, .170$ (1965). This $\S$ also anthorizes the court to consolidate this action with one challenging the form, signatures, or title 
paigns. ${ }^{128}$ Postelection review of these determinations, while not expressly prohibited, would be unlikely. ${ }^{129}$ Finally, the court is explicitly granted the discretion to separate unultisubject or revisionary measures, to ensure minimum interference with the people's initiative power. ${ }^{130}$ The proposed statutes would provide the court with an opportunity for review of comphance with the single-subject and nonrevision requirements when the costs of invalidating the initiative are lower than in postelection litigation. Thus the court would be free to develop effective standards for voter protection. ${ }^{131}$

\section{CONCLUSION}

Binding preelection review of compliance with the single-subject and nonrevision requireinents would prevent the invalidation of initiatives with curable defects, would provide a setting where inore principled and effective standards of review could develop, and would lead to greater voter protection. Moreover, preelection review of the singlesubject and nonrevision requirements is consistent doctrimally, as these requirements are nore like other requirements reviewed before the election than those reviewed only after the election. The courts are empowered to adopt an effective preelection review doctrine. Alternatively, such a program could be instituted by the legislature, as this Comment suggests. In either case, the citizens of California would be provided with needed protection of their valuable right of initiative. They would be assured that initiatives placed on the ballot would give thein the opportunity to make a clear, unequivocal, and irrevocable expression of their will.

Douglas C. Michael*

and summary, and provide preelection review of all these issues. Appendix $\S 3523.2(\mathrm{c})$, infra $\mathrm{p}$. 1237-38.

128. See supra note 122 . Oregon recognizes this by providing that judicial review "shall be conducted expeditiously to insure the orderly and timely circulation of the petition or conduct of the election . . . O" OR. REv. STAT. \& 250.085(4) (1981). Similar language is used in this proposal. See Appendix \& 3523.2(c), infra p. 1237-38.

129. See supra note 121 .

130. See Appendix $\$ 3523.2($ e), infra p. 1238. In Ohio, the courts have a sinilar power to separate a multisubject or revisionary measure if its validity would thus be curcd. See State ex rel. Hubbell v. Bettman, 124 Ohio St. 24, 176 N.E. 664 (1931).

131. See Appendix $\$ \S 3504.1$ (e), 3523.2(d), infra p. 1237-38 (directing the Attorney General and the supreme court to make voter protection their primary consideration).

* A.B. 1979, Stanford University; M.B.A. 1982, University of California, Berkeley; J.D. 1983, Boalt Hall School of Law, University of California, Berkeley. 


\section{APPENDIX \\ Proposed Amendment to the California Elections CODE}

§ 3504.1 AtToRney General; Opinion on COMPLIANCE With CoNSTITUTIONAL REQUIREMENTS

(a) Within the time provided in Sections 3503 and 3504, the Attorney General shall also determine if there is substantial doubt whether the measure complies with the following requirenents of the Constitution:

(1) that the measure embraces but one subject; and

(2) if the proposed measure amends the Constitution, that it does not constitute a revision thereof.

(b) If the Attorney General determines there is substantial doubt whether the measure complies with these requirements, he shall notify the proponents of this determination, and shall also notify them that an action will be filed to prevent submission of the measure to the voters, under Section 3523.2, if the ineasure sliould qualify for the ballot.

(c) If the Attorney General determines that there is no substantial doubt whether the measure complies with these requirements, he shall notify the proponents of this determination.

(d) The notification under subsection (b) or (c) shall also be included in the title and summary for the petition, but shall not count toward the limit on the number of words under Section 3502.

(e) In making the determination required in this Section, the Attorney General shall take imto account the potential of the measure to mislead, confuse, or deceive the signers of the initiative petition, or the voters, should the measure qualify for the ballot.

\section{$\S 3523.2$ Action to Determine Validity of Measure Submitted BY THE VOTERS}

(a) The Secretary of State shall immediately notify the Attorney General when any measure submitted by the voters qualifies for the ballot. If the Attorney General has made a determination under Section 3504.1(b) with respect to this petition, lie shall immediately apply to the Supreme Court for a writ of mandate, naming the Secretary of State as respondent, and directing the Secretary to remove the measure from the ballot. The proponents of the measure, as defined in Section 3502 , shall be served and named real parties in interest in the action.

(b) The Attorney General shall immediately publish notice of the apphication for the writ, pursuant to Section 6061 of the Government Code. After publication of notice, other interested parties may be given the opportumity to be heard before the Court.

(c) This action shall have priority over all other civil matters 
before the Court. The Court may, in its discretion, consolidate this action with any other pending action challenging the validity of the measure or its qualification on the ballot. But this action im all circumstances shall be heard and determmed as expeditiously as possible, in order to insure the orderly and timely conduct of the election.

(d) The Court shall take imto account the potential of the measure to mislead, confuse, or deceive the voters. The Court shall deny the writ if it finds that the measure complies with the constitutional requirements in Section 3504.1(a) and with any other requirements at issue in this action pursuant to consolidation under subsection (c). The Court shall grant the writ if it finds that any of these requirements have not been met.

(e) If the Court determmes that the measure is invalid, the Court . may, im its discretion, order that the measure appear as two or more separate measures on the ballot, if the Court is of the opmion that this manner of presentation would cure the invalidity, but would not defeat the expectations of the petition signers. 